Provided for non-commercial research and educational use only. Not for reproduction or distribution or commercial use.

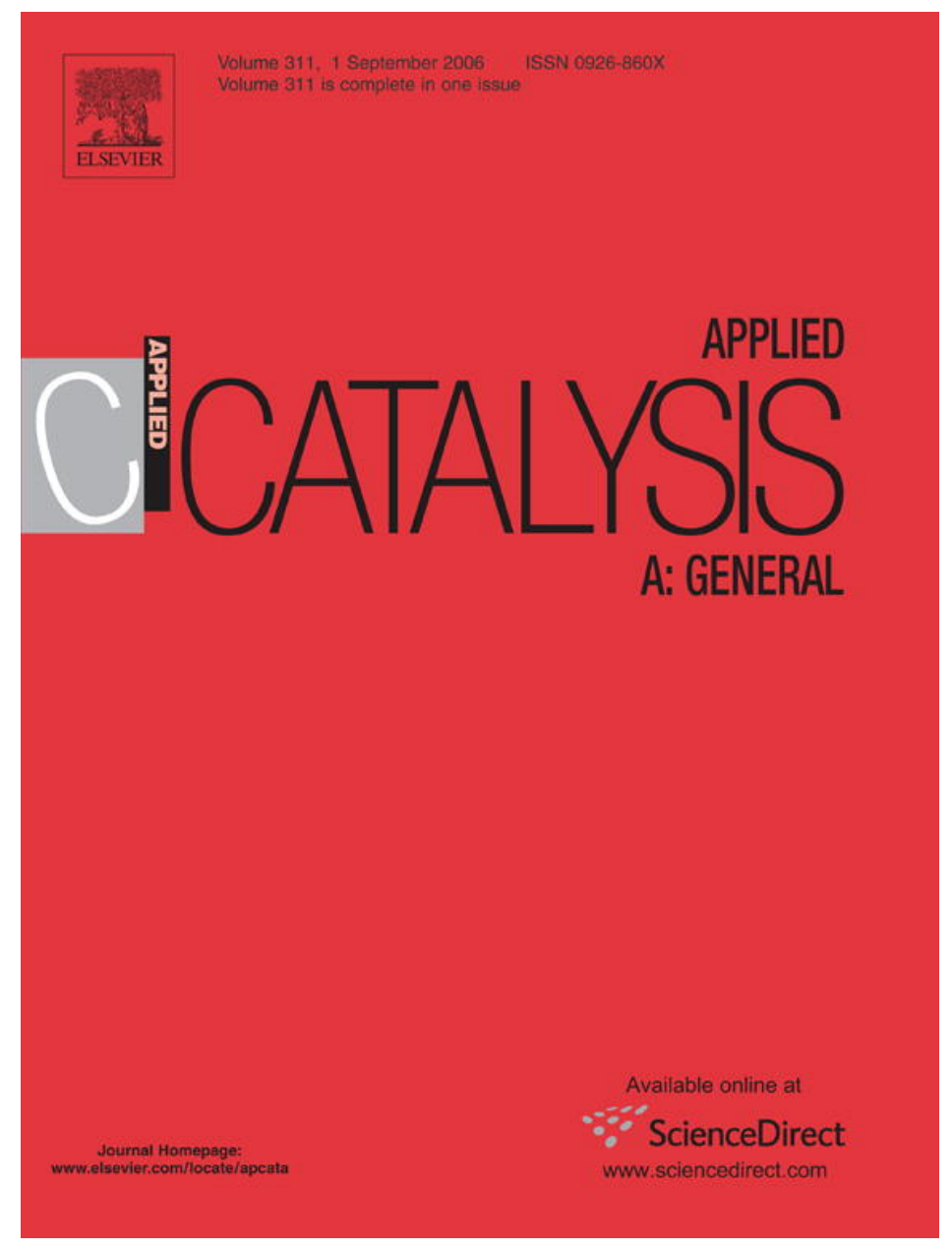

This article was originally published in a journal published by Elsevier, and the attached copy is provided by Elsevier for the author's benefit and for the benefit of the author's institution, for non-commercial research and educational use including without limitation use in instruction at your institution, sending it to specific colleagues that you know, and providing a copy to your institution's administrator.

All other uses, reproduction and distribution, including without limitation commercial reprints, selling or licensing copies or access,

or posting on open internet sites, your personal or institution's website or repository, are prohibited. For exceptions, permission may be sought for such use through Elsevier's permissions site at: 


\title{
Gold on titania: Effect of preparation method in the liquid phase oxidation
}

\author{
Nikolaos Dimitratos ${ }^{\mathrm{a}}$, Alberto Villa ${ }^{\mathrm{a}}$, Claudia L. Bianchi ${ }^{\mathrm{b}}$, \\ Laura Prati $^{\mathrm{a}, *}$, Michiel Makkee ${ }^{\mathrm{c}}$ \\ ${ }^{a}$ Dipartimento di Chimica Inorganica Metallorganica e Analitica e INSTM Unit, Centre of Excellence CIMAINA, \\ Università di Milano, via Venezian 21, 20133 Milano, Italy \\ b Dipartimento di Chimica Fisica ed Elettrochimica, Università di Milano, via Golgi 19, 20133 Milano, Italy \\ ${ }^{\mathrm{c}}$ Industrial catalysis, DelftChemTech, Faculty of Applied Sciences, Delft University of Technology, \\ Julianalaan 136, 2628 BL Delft, The Netherlands
}

Received 31 March 2006; received in revised form 13 June 2006; accepted 13 June 2006

Available online 25 July 2006

\begin{abstract}
The effect of preparation method (deposition-precipitation versus sol immobilisation method) and reduction method (calcination versus chemical reduction) on $\mathrm{Au} / \mathrm{TiO}_{2}$ catalysts for the liquid phase oxidation of glycerol has been studied. It was revealed that a different trend existed in terms of activity and distribution of products. The catalytic activity is shown to be dependent not only on the choice of the reduction method but also on the use of protective agent (PVA, THPC) for the stabilization of the gold colloids. In fact, the highest activity was found when a low temperature chemical reduction was employed on a $\mathrm{Au} / \mathrm{TiO}_{2}$ sample synthesised by the deposition-precipitation method. The use of a higher pre-treatment temperature or of a protective agent resulted in a lower activity but could be used to direct selectivity in oxidation reactions. The structural data (HRTEM and XPS) along with the catalytic results indicate that the combination of metallic $\mathrm{Au}^{0}$ species with small particle size (2-5 nm) are responsible for the high activity observed in the liquid phase oxidation of glycerol.
\end{abstract}

(C) 2006 Elsevier B.V. All rights reserved.

Keywords: Catalysis by gold; Liquid phase oxidation; Effect of preparation method

\section{Introduction}

Studies on gold supported catalysts have been mainly focused on gas-phase oxidation, such as CO oxidation [1-4], complete oxidation of hydrocarbons [5-11], selective oxidation [12-20], and water-gas shift (WGS) reaction [21-24]. Studies on the use of gold catalysts for the synthesis of fine chemicals in liquid phase have recently received much more attention. For example, it has been reported that the liquid phase oxidation of polyols [25] on Au catalysts is much more selective than Pd and Pt metals. Moreover, using Au supported catalysts enhancement of activity and stability was found. The main support used for depositing $\mathrm{Au}$ in the majority of the reported studies is activated carbon or graphite, with few examples in the use of other supports such as metal oxides. In fact, it has been shown

\footnotetext{
* Corresponding author. Tel.: +39 0250314357; fax: +39 0250314405

E-mail address: Laura.Prati@unimi.it (L. Prati).
}

that choice of metal oxide as support can play an important role in determining the catalytic activity and selectivity of the corresponding reaction [26,27].

In a previous work we reported results on the liquid phase oxidation of glycerol using mono and bimetallic catalysts based on $\mathrm{Au}, \mathrm{Pd}$ and $\mathrm{Pt}$ metals and supported on activated carbon [28] and graphite [29]. Several research groups have recently extensively studied liquid phase oxidation of glycerol due to the significant industrial importance of the products. These are important intermediates in the synthesis of fine chemicals [30]. Due to the existence of a complicated reaction network it turns out that the control in the selectivity to the desired product is difficult (Scheme 1). Efforts have been, therefore, focused on tuning the reaction pathway and logically to the selectivity to the desired products. It has been shown that depending on the reaction conditions ( $\mathrm{pH}$, temperature, substrate/metal ratio) and noble metal employed, the reaction pathway either to the primary or the secondary alcoholic group could be controlled [31-37]. The main support used for depositing noble metals 


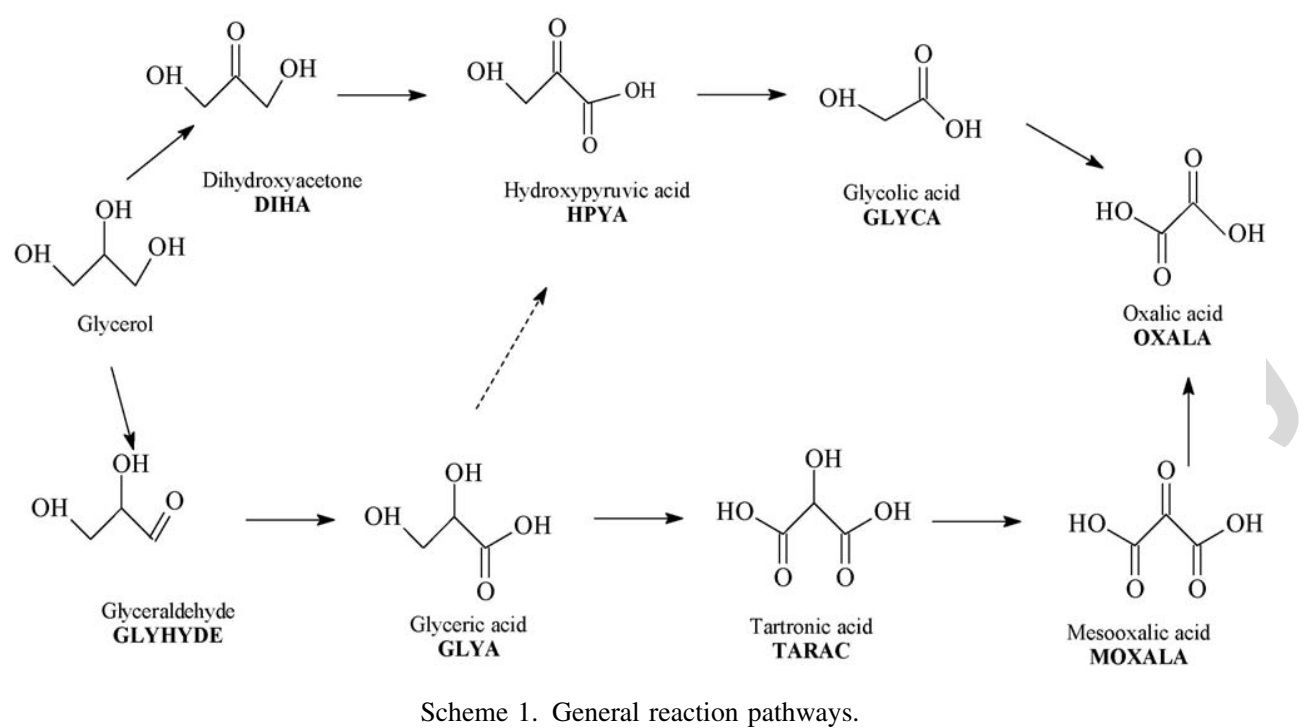

was mainly activated carbon and graphite. $\mathrm{TiO}_{2}$, on the contrary, has not been investigated till now as a support in the liquid phase oxidation of glycerol. However, recently Enache et al. [38] demonstrated the effectiveness of $\mathrm{TiO}_{2}$ as a support in the liquid phase oxidation of alcohols using $\mathrm{Au}$ and $\mathrm{Pd}$ as the main metals. Therefore, it is suggested to investigate more deeply the activity of $\mathrm{Au}$ supported on $\mathrm{TiO}_{2}$ by comparing different preparation methods. In particular, depositionprecipitation and immobilisation of preformed $\mathrm{Au}$ sol allowed to highlight a possible effect of protective molecules used in the latter method on the catalytic activity.

\section{Experimental}

\subsection{Materials}

Gold of 99.9999 purity in sponge from Fluka, $\mathrm{NaAuCl}_{4} \cdot 2 \mathrm{H}_{2} \mathrm{O} 99.0 \%$ purity from Aldrich and $\mathrm{TiO}_{2}$ purchased from Degussa (P25, S.A $=49 \mathrm{~m}^{2} / \mathrm{g}, 80 \%$ anatase), were employed. $\mathrm{NaBH}_{4}$ of purity $>96 \%$ from Fluka, polyvinylalcohol (PVA) ( $M=13,000-23,000,98 \%$ hydrolysed) and tetrakis hydroxypropyl phosphonium chloride (THPC) (98\% solution) from Aldrich were used. $\mathrm{NaOH}$ of the highest purity available was from Fluka. Gaseous oxygen from SIAD was $99.99 \%$ pure. Glycerol (88 wt.\% solution), glyceric acid and all the intermediates were obtained from Fluka. The following commercial catalyst was supplied by World Gold Council (WGC): $1.5 \% \mathrm{Au} / \mathrm{TiO}_{2}$ (Lot No 02-5, synthesised by DP).

\subsection{Preparation of the catalysts}

Monometallic catalysts based on Au supported on $\mathrm{TiO}_{2}$ were prepared by various synthetic routes: deposition-precipitation (DP) and immobilisation of metal sol.

\subsubsection{Immobilisation method}

2.2.1.1. $\mathrm{PVA} / \mathrm{NaBH}_{4}$ system. An aqueous $\mathrm{HAuCl}_{4}$ solution of $100 \mu \mathrm{g} / \mathrm{ml}$ was prepared by dissolving gold $(30 \mathrm{mg})$ in a minimum amount of $\mathrm{HCl} / \mathrm{HNO}_{3} 3 / 1$, v/v mixture and after removing $\mathrm{HNO}_{3}$; it was diluted with distilled water. Maintaining the auric solution under vigorous stirring, PVA 2 wt.\% solution was added $(\mathrm{PVA} / \mathrm{Au}(\mathrm{w} / \mathrm{w})=0.64)$; a $0.1 \mathrm{M}$ freshly prepared solution of $\mathrm{NaBH}_{4}\left(\mathrm{NaBH}_{4} / \mathrm{Au}(\mathrm{mol} / \mathrm{mol})=5\right)$ was then added to form a ruby-red metallic sol.

2.2.1.2. THPC/NaOH system. Sol generated in the presence of the THPC/ $\mathrm{NaOH}$ system was prepared as reported elsewhere [39] and used as such. A freshly prepared solution $0.05 \mathrm{M}$ of THPC was added (THPC/Au $(w / w)=0.95)$ to a $\mathrm{NaOH}$ solution $\left(10^{-3} \mathrm{M}\right)$. After a few minutes $\mathrm{HAuCl}_{4}\left(1 \times 10^{-3} \mathrm{M}\right)$ was added dropwise, forming a brown metallic sol.

Within a few minutes of sol generation, the sol was immobilised by adding $\mathrm{TiO}_{2}$ (acidified at $\mathrm{pH} 1$, by sulfuric acid) under vigorous stirring and aged for $1 \mathrm{~h}$. The amount of support was calculated as having a final gold loading of $1 \mathrm{wt} . \%$. After filtration, a colourless filtrate indicated (verified by UV-vis spectra) that all the gold particles were embedded onto the $\mathrm{TiO}_{2}$; the samples have been washed for several times to ensure the removal of the material arising from the reduction treatment. The samples were dried at $373 \mathrm{~K}$ for $2 \mathrm{~h}$.

ICP analyses were performed on the filtrate using a Jobin Yvon JV24 to verify the gold loading on $\mathrm{TiO}_{2}$.

\subsubsection{Deposition-precipitation method (DP)}

For the DP preparation the support was dispersed in water (approximately $10 \mathrm{ml} / \mathrm{g}$ of support) to which ammonia was added to raise the $\mathrm{pH}$ to a value between 9 and 10. The advantage of using $\mathrm{NH}_{3}$ was to control the $\mathrm{pH}$ more easily and to avoid formation of residues produced from other bases. Nevertheless it should be emphasized that by using ammonia in the presence of gold salts can lead to the production of explosive fulminating gold [40]. Over a time interval of $2 \mathrm{~h}$ the required amount of gold (in the form of $\mathrm{AuCl}_{3}$ solution) was added drop wise to the support under vigorous stirring. The mixture was stirred for $30 \mathrm{~min}$ after which it was centrifuged and washed with at least 10 times its own volume of distilled 
water. The reduction of the catalyst was carried out by using two methods (calcination versus chemical reduction at room temperature).

(a) Calcination: the dried $1 \% \mathrm{AuTiO}_{2}$ was calcined at $723 \mathrm{~K}$ in air for $4 \mathrm{~h}$.

(b) Chemical reduction: The required amount of $1 \% \mathrm{Au} / \mathrm{TiO}_{2}$ was suspended in distilled water and then a solution of $\mathrm{NaBH}_{4}(0.1 \mathrm{M})$ was prepared and added in the required amount $\left(\mathrm{NaBH}_{4} / \mathrm{Au}(\mathrm{mol} / \mathrm{mol})=5\right)$ under vigorous stirring at room temperature. The sample was dried at $373 \mathrm{~K}$ for $2 \mathrm{~h}$.

(c) Chemical reduction/calcination: The chemical reduced catalyst with $\mathrm{NaBH}_{4}$ was calcined at $723 \mathrm{~K}$ in air for $4 \mathrm{~h}$.

\subsubsection{Characterisations}

2.2.3.1. Sol characterisation. UV-vis spectra of sols were performed on HP8452 and HP8453 Hewlett-Packard spectrophotometers in $\mathrm{H}_{2} \mathrm{O}$ between 190 and $1200 \mathrm{~nm}$, in a quartz cuvette.

2.2.3.2. Catalyst characterisation. XPS measurements were performed in an M-Probe Instrument (SSI) equipped with a monochromatic $\mathrm{Al} \mathrm{K} \alpha$ source $(1486.6 \mathrm{eV})$ with a spot size of $200 \mu \mathrm{m} \times 750 \mu \mathrm{m}$ and a pass energy of $25 \mathrm{eV}$, providing a resolution for $0.74 \mathrm{eV}$. The accuracy of the reported binding energies (BE) can be estimated to be $\pm 0.2 \mathrm{eV}$. The quantitative data were checked accurately and reproduced several times (at least 10 times for each sample). A curve fitting procedure of the experimental spectra was done.

Transmission electron microscopic investigations (TEM and HRTEM) were carried out using a Tecnai F20 transmission electron microscope operated at $200 \mathrm{kV}$. Samples were crushed and dusted on a hollow coated copper TEM grid.

\subsection{Oxidation experiments}

The reactions were carried out at $50{ }^{\circ} \mathrm{C}$ in a thermostatted glass reactor provided with an electronically controlled magnetic stirrer connected to a large reservoir $(5000 \mathrm{ml})$ containing oxygen at $300 \mathrm{kPa}$. The oxygen uptake was followed by a mass-flow controller connected to a PC through an A/D board, plotting a flow/time diagram.

An aqueous solution of glycerol ( $0.3 \mathrm{M}, 10 \mathrm{ml}$ total volume) was prepared and mixed with the desired amount of $\mathrm{NaOH}$ and catalyst $($ glycerol $/ \mathrm{metal}=500 \mathrm{~mol} / \mathrm{mol}, \mathrm{NaOH} /$ glycerol $=4$ $\mathrm{mol} / \mathrm{mol}$ ). The reactor was pressurised at $300 \mathrm{kPa}$ of $\mathrm{O}_{2}$ and thermostatted at the appropriate temperature. After an equilibration time of $10 \mathrm{~min}$, the reaction was initiated by stirring and samples were taken periodically (15-30 $\mathrm{min}$ ) and analysed by HPLC.

\subsection{Analysis of products}

Analysis of products was performed on a Varian $9050 \mathrm{UV}$ $(210 \mathrm{~nm})$ and a Waters R.I. detector in series. An Altech OA10308 column $(300 \mathrm{~nm} \times 6.5 \mathrm{~nm})$ was used with aqueous $\mathrm{H}_{3} \mathrm{PO}_{4} 0.1 \mathrm{wt} . \%$. as the eluent. Samples of the reaction mixture
$(0.5 \mathrm{ml})$ were diluted in $5 \mathrm{ml}$ using the eluent. Products were recognised by comparison with authentic samples.

\section{Results and discussion}

\subsection{Effect of reduction method}

Catalytic testing was performed using as a model reaction the oxidation of glycerol in water at $50{ }^{\circ} \mathrm{C}$ under alkaline conditions. The major products of the glycerol oxidation were salts of glyceric, glycolic and tartronic acids, with minor products to be salts of hydroxypyruvic and oxalic acids. In order to evaluate the effect of reduction method (calcination or chemical reduction), the following tests were performed using as a reference catalyst a $1 \% \mathrm{Au} / \mathrm{TiO}_{2}$ synthesised by DP in the dried form (not calcined). XPS analysis of the $\mathrm{Au} 4 \mathrm{f}$ region was carried out (Fig. 1). In this region each gold species showed two peaks due to the $\mathrm{Au} 4 \mathrm{f}_{7 / 2}$ and to the $\mathrm{Au} 4 \mathrm{f}_{5 / 2}$ transitions. In the following the values of binding energies (BE) will be referred to the $\mathrm{Au} 4 \mathrm{f}_{7 / 2}$ peak. Catalytic testing of the dried form (uncalcined sample) of the $1 \% \mathrm{Au} / \mathrm{TiO}_{2}$ did not show any activity at all (Table 1). However, XPS data (Table 1, entry 1) revealed the presence of two oxidation states for gold ( $\mathrm{Au}{ }^{\mathrm{III}}$ at $85.1 \mathrm{eV}$ and $\mathrm{Au}^{0}$ at $83.9 \mathrm{eV}$ ) in equal composition. Specifically, the peak at $85.1 \mathrm{eV}$ has been assigned to $\mathrm{Au}^{\mathrm{III}}$ species [41]. Moreover, HRTEM and HAADF (high angle annular dark field) analysis (Figs 2a and 3a), respectively, confirmed the presence of fine gold particles of 1-1.5 nm. Mössbauer analysis on the same sample provided the proof that only Au(III) species were present [42]. It has been however reported [43] that the reduction of $\mathrm{Au}^{\mathrm{III}}$ species on the $\mathrm{TiO}_{2}$ is possible to take place in ambient air and light, resulting in the formation of large particle size $(5-7 \mathrm{~nm})$. Moreover, reduction of $\mathrm{Au}^{\mathrm{III}}$ could also occurred during the TEM or XPS analysis due to the electron beam and photon beam, respectively. From HRTEM analysis of $1 \% \mathrm{Au} / \mathrm{TiO}_{2}$ uncalcined the particle size dimension was in the range of $1-1.5 \mathrm{~nm}$, which is in agreement with the reported data [43]. Thus, we can suggest that the fine particles we observed in the uncalcined sample of $\mathrm{Au} / \mathrm{TiO}_{2}$ are possibly due to the reduction of $\mathrm{Au}^{\mathrm{III}}-\mathrm{Au}^{0}$ by the electron beam (HRTEM).

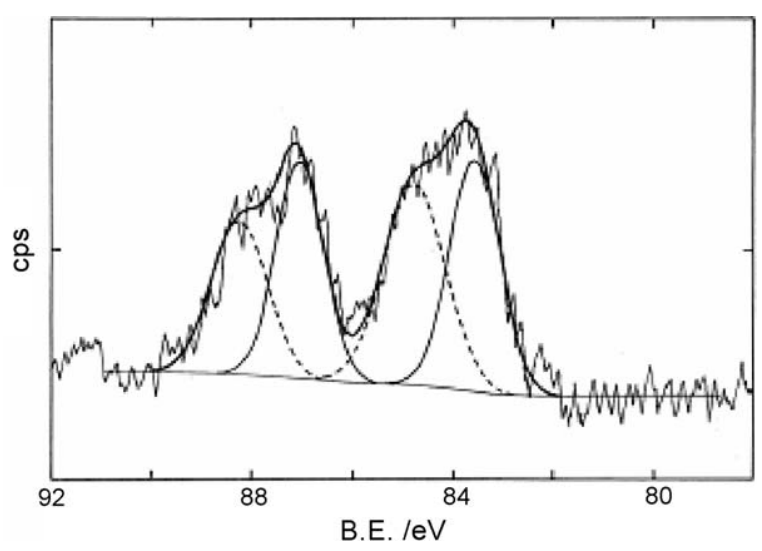

Fig. 1. XPS spectrum of the $\mathrm{Au} 4 \mathrm{f}$ region of $1 \% \mathrm{Au} / \mathrm{TiO}_{2}$ synthesised by $\mathrm{DP}$ in the dried form. $\mathrm{Au} 4 \mathrm{f}_{7 / 2}$ and $5 / 2$ doublets relative to the different Au spectral components: $\mathrm{Au}(0)$, continuous line and $\mathrm{Au}(\mathrm{III})$, dotted line. 
Table 1

XPS, HRTEM and catalytic activity ${ }^{\mathrm{a}}$ (TOF) data

\begin{tabular}{|c|c|c|c|c|c|c|}
\hline$\overline{\text { Entry }}$ & Samples & $\mathrm{BE}(\mathrm{eV}) \mathrm{Au} 4 \mathrm{f}_{7 / 2}$ & Oxidation state & Percentage at $\mathrm{Au}\left(4 \mathrm{f}_{7 / 2}\right)$ & $d(\mathrm{~nm}) \mathrm{HRTEM}$ & TOF $\left(h^{-1}\right)^{b}$ \\
\hline \multirow[t]{2}{*}{1} & $1 \% \mathrm{AuTiO}_{2}$ & $83.9(48 \%)$ & $\mathrm{Au}(0)$ & \multirow[t]{2}{*}{0.6} & \multirow[t]{2}{*}{$1-2$} & \multirow[t]{2}{*}{-} \\
\hline & $\mathrm{DP}$ & $85.1(52 \%)$ & $\mathrm{Au}(\mathrm{III})$ & & & \\
\hline \multirow[t]{2}{*}{2} & $1 \% \mathrm{AuTiO}_{2}$ & $83.7(80 \%)$ & $\mathrm{Au}(0)$ & \multirow[t]{2}{*}{0.05} & \multirow[t]{2}{*}{5} & \multirow[t]{2}{*}{113} \\
\hline & DP/calcined & $84.8(20 \%)$ & $\mathrm{Au}(\delta+)$ & & & \\
\hline \multirow[t]{2}{*}{3} & $1 \% \mathrm{AuTiO}_{2}$ & 83.8 & $\mathrm{Au}(0)$ & \multirow[t]{2}{*}{0.4} & \multirow[t]{2}{*}{$2-5$} & \multirow[t]{2}{*}{721} \\
\hline & $\mathrm{DP} \mathrm{NaBH}_{4}$ & & & & & \\
\hline \multirow[t]{2}{*}{4} & $1 \% \mathrm{AuTiO}_{2}$ & $83.7(83 \%)$ & $\mathrm{Au}(0)$ & \multirow[t]{2}{*}{0.1} & $>25$ & \multirow[t]{2}{*}{$<10$} \\
\hline & DP $\mathrm{NaBH}_{4} /$ calcined & $85.2(17 \%)$ & $\mathrm{Au}(\mathrm{III})$ & & Agglomerate of $100 \mathrm{~nm}$ & \\
\hline 5 & $\begin{array}{l}1 \% \mathrm{Au} / \mathrm{TiO}_{2} \\
\mathrm{THPC}\end{array}$ & 83.8 & $\mathrm{Au}(0)$ & 0.2 & $2-3$ & 367 \\
\hline 6 & $\begin{array}{l}1 \% \mathrm{Au} / \mathrm{TiO}_{2} \\
\text { PVA }\end{array}$ & 83.9 & $\mathrm{Au}(0)$ & 0.2 & & 178 \\
\hline 7 & $\begin{array}{l}1.5 \% \mathrm{Au} / \mathrm{TiO}_{2} \\
\text { WGC }\end{array}$ & 83.7 & $\mathrm{Au}(0)$ & 0.4 & 4 & 203 \\
\hline
\end{tabular}

${ }^{\mathrm{a}}$ Reaction conditions: water $10 \mathrm{ml}, 0.3 \mathrm{M}$ glycerol, glycerol $(\mathrm{M})=500, \mathrm{NaOH} /$ glycerol $=4, T=50{ }^{\circ} \mathrm{C}, p \mathrm{O}_{2}=3 \mathrm{~atm}$.

${ }^{\mathrm{b}}$ Calculation of TOF $\left(\mathrm{h}^{-1}\right)$ after $0.5 \mathrm{~h}$ of reaction. TOF numbers were calculated on the basis of total loading of metals $\mathrm{S}_{50}$, $\mathrm{S}_{90}$ indicate the selectivity observed at $50 \%$ and $90 \%$ conversion, respectively.

The catalyst was reduced with $\mathrm{NaBH}_{4}$ or by calcination at $723 \mathrm{~K}$. A significant activity was found for the former sample (Table 1, entry 3) (increase of TOF up to six times of magnitude). In this case, XPS data confirmed only the presence of $\mathrm{Au}$ in the metallic state, (peak at $83.8 \mathrm{eV}$ ), whereas the gold particles were in the range of $2-5 \mathrm{~nm}$ indicating a narrow size

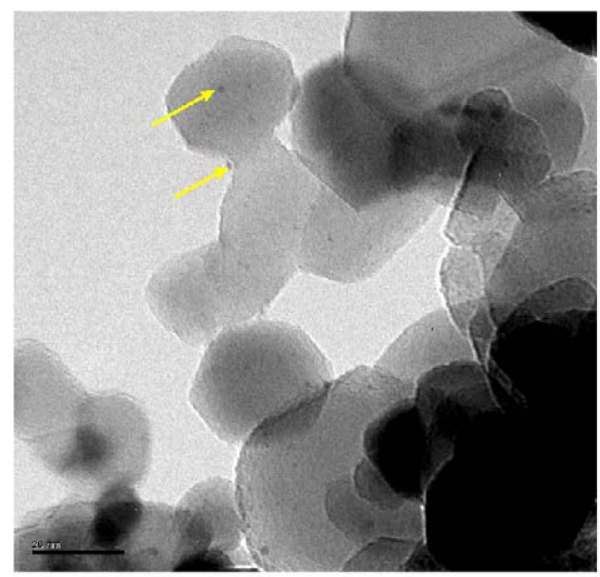

(a) distribution (Fig. 2c). Calcination of the dried sample resulted in a higher amount of $\mathrm{Au}^{0}$ species $(80 \%$ for $83.8 \mathrm{eV}$ and $20 \%$ for $84.8 \mathrm{eV}$ ) with respect to the dried sample and in addition a negative shift of the peak at $85.2-84.8 \mathrm{eV}$ was found. The peak at $84.8 \mathrm{eV}$ is an intermediate value to that reported ones for $\mathrm{Au}^{0}$ and $\mathrm{Au}^{\mathrm{III}}$, thus can be assigned to $\mathrm{Au}^{\delta+}$ species. HRTEM data

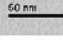

(b)

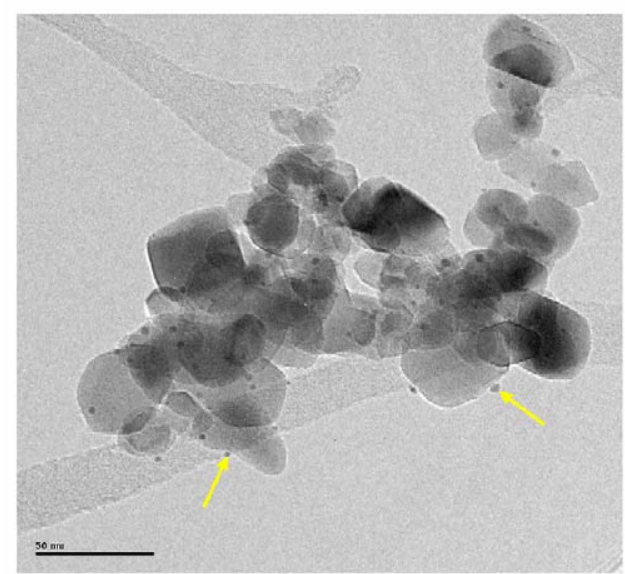

(c)

Fig. 2. HRTEM images of supported gold catalysts: (a) $1 \% \mathrm{Au} / \mathrm{TiO}_{2}-\mathrm{DP}$ (dried form), (b) $1 \% \mathrm{Au} / \mathrm{TiO}_{2}-\mathrm{DP}$ (calcined form), and (c) $1 \% \mathrm{Au} / \mathrm{TiO}{ }_{2}(\mathrm{DP} / \mathrm{NaBH}$ ). 

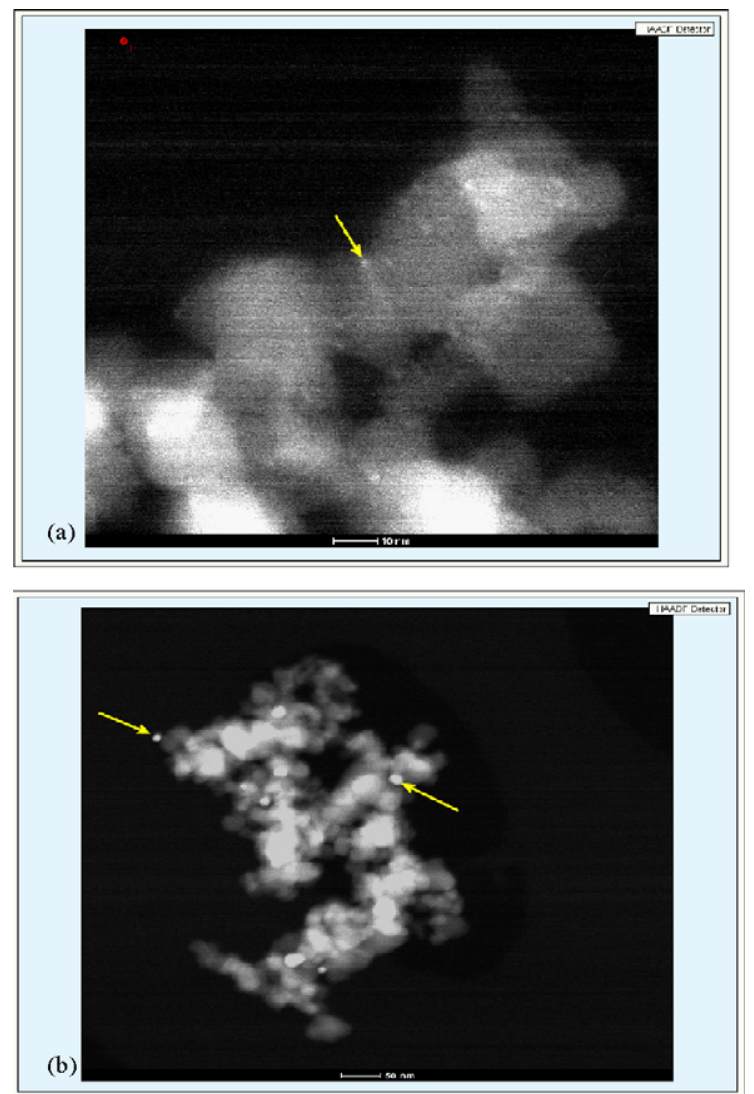

Fig. 3. HAADF images of supported gold catalysts: (a) $1 \% \mathrm{Au} / \mathrm{TiO}_{2}-\mathrm{DP}$ (dried form) and (b) $1 \% \mathrm{Au} / \mathrm{TiO}_{2}-\left(\mathrm{DP} / \mathrm{NaBH}_{4} /\right.$ calcined form).

showed a growth of the gold particles, the mean gold diameter being $5.2 \mathrm{~nm}$ (Fig. 2b).

The effect of calcination was also studied for the $\mathrm{Au} / \mathrm{TiO}_{2}$ chemically reduced by $\mathrm{NaBH}_{4}$. Catalytic data showed a significant reduction of the activity with respect to the uncalcined $\mathrm{Au} / \mathrm{TiO}_{2}$ only reduced by $\mathrm{NaBH}_{4}$ (Table 1, entry 4). This result is supported considering the characterisation data. The calcination was detrimental for small sized gold particles and significant growth and agglomeration was found with gold particle size ranging from 9 to $25 \mathrm{~nm}$, as HAADF images (Fig. 3b) revealed. In addition, XPS data revealed the presence of two oxidation states for $\mathrm{Au}\left(\mathrm{Au}^{0}\right.$ at $83.7 \mathrm{eV}$ and $\mathrm{Au}^{\mathrm{III}}$ at $85.2 \mathrm{eV}$ ). The increase of temperature lead to a negative shift of the peak corresponding to $\mathrm{Au}^{0}$ (from 83.8 to $83.7 \mathrm{eV}$ ). Normally, this shift can be assigned to the changes in electronic structure with increasing gold particle size [44,42]. The presence of $\mathrm{Au}(\mathrm{III})$ species could be explained by a strong interaction with the support.

These results indicate clearly that only when Au was gradually reduced from $\mathrm{Au}^{\mathrm{III}}$ to $\mathrm{Au}^{0}$ the activity of the gold catalysts was significantly enhanced. This remark would be proper if the mean gold particle diameter was similar in all the samples. However, since this is not the actual case the particle size dimension of the gold particles has to be also taken into consideration. Thus, gold particles on $\mathrm{TiO}_{2}$ presented the highest activity when the particles were in the range of 2-5 nm. XPS data confirms that $\mathrm{Au}^{\mathrm{III} / \delta+}$ species can be excluded as the active phase in the liquid phase oxidation of glycerol and therefore consider $\mathrm{Au}^{0}$ to be the most important sites for oxidation process.

\subsection{Effect of preparation method}

It is worth noting that gold catalyst activity depends on preparation method, but sometimes the comparison is difficult for the lacking of a correct term of comparison. Therefore, a commercially available $\mathrm{Au} / \mathrm{TiO}_{2}$ (supplied by WGC) was taken as a reference and compared its activity in the liquid phase glycerol oxidation with another catalyst prepared by sol immobilisation. $\mathrm{Au} / \mathrm{TiO}_{2}$ prepared by us with similar procedure of the commercial sample (DP-calcined) was used.

\subsubsection{Sol immobilisation method}

Monometallic catalysts based on Au supported on $\mathrm{TiO}_{2}$ were synthesised, by using the sol immobilisation method. Specifically for sol preparation, two procedures were used, one based on the PVA/ $/ \mathrm{NaBH}_{4}$ system and the other on the THPC/NaOH system. The choice of different experimental conditions in the preparation of sols (amount of $\mathrm{NaBH}_{4}, \mathrm{Au}$ precursor and protective agent) was based on previous results that demonstrated the correlation between optimum activity, particle size and amount of protective agent [26]. XPS revealed in both cases only the presence of metallic gold. In Tables 1 and 2 the results are presented. It is apparent that the choice of the sol preparation method [26,45] affected not only the activity but also the distribution of the products. Using THPC/NaOH, the particle size dimension is in the range of $2-3 \mathrm{~nm}$, whereas in the case of the PVA/ $\mathrm{NaBH}_{4}$, in the range of $4-5 \mathrm{~nm}$.

Actually, in terms of activity the THPC/NaOH system resulted in the synthesis of the most active catalyst, whereas in terms of selectivity the catalyst prepared by the PVA/ $\mathrm{NaBH}_{4}$ system exhibited the highest selectivity to glycerate. After reaching full conversion the reaction was proceeded for 4-6 h. With the $1 \% \mathrm{Au} / \mathrm{TiO}_{2}(\mathrm{THPC} / \mathrm{NaOH})$ catalyst, glycerate was further oxidised to tartronate (selectivity to glycerate decreased up to 20\%) as it is illustrated in Fig. 4. These results can be explained considering the particle size of the two referred catalysts. It was recently demonstrated [46] that a progressive increase of particle size will lead to a significant decrease in terms of activity, whereas in terms of selectivity an increase in the selectivity to glycerate will occur, which is in agreement with the obtained data (Table 2, entries 3 and 4). For comparison we also reported catalytic results obtained using similar conditions with the catalyst 1\%Au-PVA but supported on activated carbon [28] (Table 2, entry 6). The effect of the support can be seen mainly on the activity of the catalyst (TOF $1090 \mathrm{~h}^{-1}$ versus $178 \mathrm{~h}^{-1}$ ), whereas selectivity appeared to be ruled mainly by metal particle itself (similar sized and protected particle generated similar selectivity).

\subsubsection{Deposition-precipitation method (DP)}

For the synthesis of Au catalysts supported on $\mathrm{TiO}_{2}$ the DP method was used. In addition, a commercial catalyst supplied from World Gold Council $\left(1.5 \% \mathrm{Au} / \mathrm{TiO}_{2}\right.$, Lot No 02-5, 
Table 2

Oxidation of glycerol using different preparation methods at $50{ }^{\circ} \mathrm{C}^{\mathrm{a}}$

\begin{tabular}{|c|c|c|c|c|c|c|c|c|}
\hline \multirow[t]{2}{*}{ Entry } & \multirow[t]{2}{*}{ Catalysts } & \multicolumn{7}{|c|}{ Selectivity (\%) } \\
\hline & & $\overline{\mathbf{S}}$ & GLYA & GLYCA & OXALA & HPYA & TARAC & $\overline{\text { TOF }\left(h^{-1}\right)^{b}}$ \\
\hline \multirow[t]{2}{*}{1} & $1 \% \mathrm{Au} / \mathrm{TiO}_{2}$ & $\mathrm{~S}_{50}$ & 81 & 13 & 0 & 2 & 4 & 113 \\
\hline & DP/Calcined & $\mathrm{S}_{90}$ & - & - & - & - & - & \\
\hline \multirow[t]{2}{*}{2} & $1 \% \mathrm{Au} / \mathrm{TiO}_{2}$ & $\mathrm{~S}_{50}$ & 55 & 28 & 0 & 0 & 17 & 721 \\
\hline & $\mathrm{DP} / \mathrm{NaBH}_{4}$ & $\mathrm{~S}_{90}$ & 62 & 26 & 0 & 0 & 12 & \\
\hline \multirow[t]{2}{*}{3} & $1 \% \mathrm{Au} / \mathrm{TiO}_{2}$ & $\mathrm{~S}_{50}$ & 55 & 15 & 4 & 1 & 25 & 367 \\
\hline & THPC & $\mathrm{S}_{90}$ & 52 & 15 & 4 & 1 & 28 & \\
\hline \multirow[t]{2}{*}{4} & $1 \% \mathrm{Au} / \mathrm{TiO}_{2}$ & $\mathrm{~S}_{50}$ & 52 & 13 & 9 & 2 & 24 & 178 \\
\hline & PVA & $\mathrm{S}_{90}$ & 69 & 17 & 2 & 2 & 10 & \\
\hline \multirow[t]{2}{*}{5} & $1.5 \% \mathrm{Au} / \mathrm{TiO}_{2}$ & $\mathrm{~S}_{50}$ & 64 & 23 & 1 & 1 & 11 & 203 \\
\hline & WGC & $\mathrm{S}_{90}$ & 60 & 23 & 2 & 3 & 12 & \\
\hline \multirow[t]{2}{*}{$6^{c}$} & $1 \% \mathrm{Au} / \mathrm{AC}^{\mathrm{d}}$ & $\mathrm{S}_{50}$ & 64 & 12 & 9 & 4 & 9 & 1090 \\
\hline & PVA & $\mathrm{S}_{90}$ & 52 & 12 & 23 & 2 & 10 & \\
\hline
\end{tabular}

${ }^{\mathrm{a}}$ Reaction conditions: water $10 \mathrm{ml}, 0.3 \mathrm{M}$ glycerol, glycerol $(\mathrm{M})=500, \mathrm{NaOH} /$ glycerol $=4, T=50{ }^{\circ} \mathrm{C}, p \mathrm{O}_{2}=3 \mathrm{~atm}$.

${ }^{\mathrm{b}}$ Calculation of TOF $\left(\mathrm{h}^{-1}\right)$ after $0.5 \mathrm{~h}$ of reaction. TOF numbers were calculated on the basis of total loading of metals $\mathrm{S}_{50}$, $\mathrm{S}_{90}$ indicate the selectivity observed at $50 \%$ and $90 \%$ conversion, respectively.

c From Ref. [28].

d Activated carbon.

synthesised by DP) was used. As an example the reaction profile of $1.5 \% \mathrm{Au} / \mathrm{TiO}_{2}$ is shown (Fig. 5). It can be seen that as the conversion increased the selectivity to glycerate decreased and the main by-products were glycolate and tartronate.

In terms of activity, $1.5 \% \mathrm{Au} / \mathrm{TiO}_{2}$ (WGC) resulted to a higher activity than the $1 \% \mathrm{Au} / \mathrm{TiO}_{2} \mathrm{DP} /$ calc., whereas in the case of selectivity to glycerate, at the same conversion level (e.g. at $50 \%$ conversion) higher selectivity was observed for the $1 \% \mathrm{Au} / \mathrm{TiO}_{2} \mathrm{DP} /$ calc. catalyst. These results can be interpreted by taking into account the characterisation data obtained by XPS and TEM analysis. TEM analysis showed that a smaller particle size exists for the $1.5 \% \mathrm{Au} / \mathrm{TiO}_{2}$ catalyst $(4 \mathrm{~nm}$ ) than for the $1 \% \mathrm{Au} / \mathrm{TiO}_{2}(5 \mathrm{~nm})$. However, this small decrease of the gold particle size cannot explain the double increase of TOF value (203 versus $113 \mathrm{~h}^{-1}$ ). In fact taking into consideration the XPS data for the $1.5 \% \mathrm{Au} / \mathrm{TiO}_{2}$ (WGC), the presence of only one peak assigned to metallic $\mathrm{Au}^{0}$ was detected at $83.8 \mathrm{eV}$, whereas for $1 \% \mathrm{Au} / \mathrm{TiO}_{2}$, the presence of an additional peak at $85.1 \mathrm{eV}$ was found and it was assigned to $\mathrm{Au}{ }^{\mathrm{III}}$ species, with $\mathrm{Au}^{0}$ to be the major component $(80 \%)$. From these results we can hypothesise that the presence of $\mathrm{Au}^{\mathrm{III}}$ species can be detrimental for the activity.

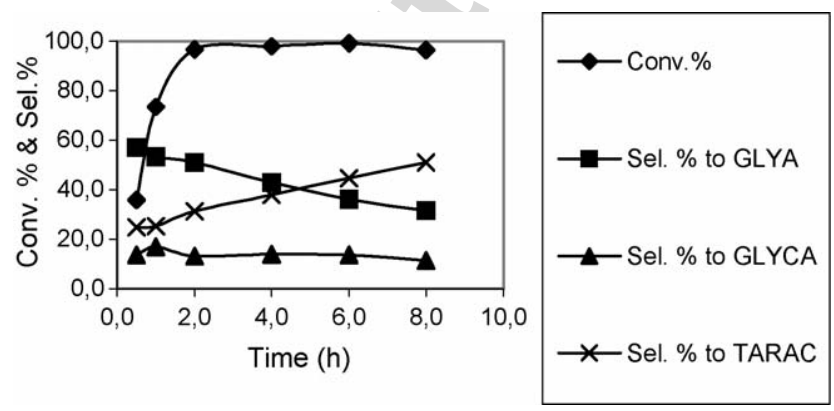

Fig. 4. Selective oxidation of glycerol in the presence of $1 \% \mathrm{Au} / \mathrm{TiO}_{2}(\mathrm{THPC} /$ $\mathrm{NaOH}$ ). Reaction conditions: water $10 \mathrm{ml}, 0.3 \mathrm{M}$ glycerol, glycerol $(\mathrm{M})=500$, $\mathrm{NaOH} /$ glycerol $=4, T=50{ }^{\circ} \mathrm{C}, p \mathrm{O}_{2}=3 \mathrm{~atm}$.

\subsubsection{Comparison of the different synthetic approaches}

It is of interest to compare and evaluate the catalyst activities of the two main synthetic methods (deposition-precipitation versus Immobilisation method) utilised for the preparation of the $\mathrm{Au} / \mathrm{TiO}_{2}$ catalysts. However, the evaluation should be considered at similar particle dimension. In this way the role of reduction method (chemical or calcination) and protective agent can be interpreted more clearly.

The role of the protective agent was clearly shown from the catalytic data obtained with $1 \% \mathrm{Au} / \mathrm{TiO}_{2}$ prepared by DP/ $\mathrm{NaBH}_{4}$ and $1 \% \mathrm{Au} / \mathrm{TiO}_{2}$ synthesised by $\mathrm{PVA} / \mathrm{NaBH}_{4}$ (Table 2, entries 2 and 4). XPS data showed the presence only of metallic $\mathrm{Au}^{0}$, while particle size was in a similar range; the activity of the former was up to four times more than the latter sample. This result leads to the conclusion that the protective layer (PVA) affects to a certain level the intrinsic reactivity of the gold particle, since the same amount of $\mathrm{NaBH}_{4}\left(\mathrm{NaBH}_{4} /\right.$ $\mathrm{Au}=5 \mathrm{~mol} / \mathrm{mol}$ ) was used in both cases.

Moreover, the $1 \% \mathrm{Au} / \mathrm{TiO}_{2}$ prepared by $\mathrm{DP} / \mathrm{NaBH}_{4}$ resulted in a higher activity than the $1 \% \mathrm{Au} / \mathrm{TiO}_{2}$ prepared by THPC, even if the second possessed smaller gold particle size. This

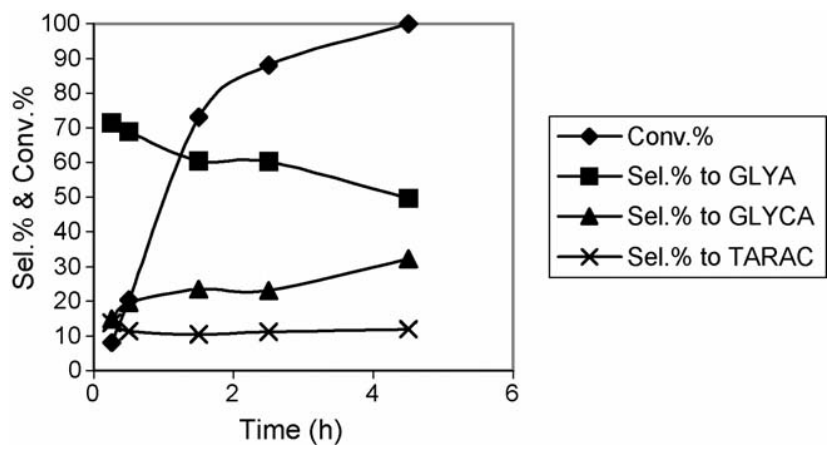

Fig. 5. Selective oxidation of glycerol in the presence of $1.5 \% \mathrm{Au} / \mathrm{TiO}_{2}$ (deposition-precipitation method). Reaction conditions: water $10 \mathrm{ml}, 0.3 \mathrm{M}$ glycerol, glycerol $(\mathrm{M})=500, \mathrm{NaOH} /$ glycerol $=4, T=50^{\circ} \mathrm{C}, p \mathrm{O}_{2}=3 \mathrm{~atm}$. 
Table 3

Comparison of catalytic and characterisation data of catalysts prepared by different synthetic methods ${ }^{\mathrm{a}}$

\begin{tabular}{|c|c|c|c|c|c|c|}
\hline \multirow[t]{2}{*}{ Entry } & \multirow[t]{2}{*}{ Samples } & \multicolumn{3}{|c|}{$\mathrm{S}_{50}-\mathrm{S}_{90}$} & \multirow[t]{2}{*}{$d(\mathrm{~nm})$ HRTEM } & \multirow[t]{2}{*}{$\operatorname{TOF}\left(h^{-1}\right)^{b}$} \\
\hline & & GLYA & GLYCA & TARAC & & \\
\hline 1 & $1 \% \mathrm{Au} / \mathrm{TiO}_{2}(\mathrm{DP} /$ calcined $)$ & 81 & 13 & 4 & 5 & 113 \\
\hline 2 & $1 \% \mathrm{Au} / \mathrm{TiO}_{2}\left(\mathrm{DP} / \mathrm{NaBH}_{4}\right)$ & $55-62$ & $28-26$ & $17-12$ & $2-5$ & 721 \\
\hline 3 & $1 \% \mathrm{Au} / \mathrm{TiO}_{2}(\mathrm{THPC})$ & $55-52$ & $15-15$ & $25-28$ & $2-3$ & 367 \\
\hline 4 & $1 \% \mathrm{Au} / \mathrm{TiO}_{2}(\mathrm{PVA})$ & $52-69$ & $13-17$ & $24-10$ & $4-5$ & 178 \\
\hline 5 & $1.5 \% \mathrm{Au} / \mathrm{TiO}_{2}(\mathrm{WGC})$ & $64-60$ & $23-23$ & $11-12$ & 4 & 203 \\
\hline $6^{\mathrm{c}}$ & $1 \% \mathrm{Au} / \mathrm{AC}^{\mathrm{d}}(\mathrm{PVA})$ & $64-52$ & $12-12$ & $9-10$ & 5 & 1090 \\
\hline
\end{tabular}

${ }^{\text {a }}$ Reaction conditions: water $10 \mathrm{ml}, 0.3 \mathrm{M}$ glycerol, glycerol $(\mathrm{M})=500, \mathrm{NaOH} /$ glycerol $=4, T=50{ }^{\circ} \mathrm{C}, p \mathrm{O}_{2}=3 \mathrm{~atm}$.

${ }^{\mathrm{b}}$ Calculation of TOF $\left(\mathrm{h}^{-1}\right)$ after $0.5 \mathrm{~h}$ of reaction. TOF numbers were calculated on the basis of total loading of metals $\mathrm{S}_{50}, \mathrm{~S}_{90}$ indicate the selectivity observed at $50 \%$ and $90 \%$ conversion, respectively.

c From Ref. [28].

d Activated carbon.

result confirms the above argument that the protective layer affects the intrinsic activity of gold supported particles.

Finally $1 \% \mathrm{Au} / \mathrm{TiO}_{2}$ prepared by DP compared with commercial sample, even presenting similar particle size, showed different activity probably due to the different gold species (XPS data). Moreover, comparison of activities of $1 \% \mathrm{Au} / \mathrm{TiO}_{2}$ prepared by $\mathrm{DP} / \mathrm{NaBH}_{4}$ and the commercial one showed that the former presented a considerably higher activity. As in both cases XPS shows only $\mathrm{Au}(0)$ specie and TEM similar particle size, we can also conclude that chemical reduction method produce more active catalyst than calcination method.

In terms of selectivity, since from a practical point of view the selectivity represents a crucial task, the influence of preparation method on this parameter was also observed.

It was recently shown [46] that a progressive increase of particle size would lead to an increase in the selectivity to glycerate, mainly due to the suppression of the over-oxidation of glycerate acid to tartronate. Roughly this trend could be also seen in actual data: more active was the catalyst less selective to glycerate (Table 3 ).

However, some other factor could be envisaged in determining selectivity to glycerate: considering $S_{90}$ instead of $S_{50}$ we observed that in some cases $S_{90}$ resulted higher than $\mathrm{S}_{50}$ meaning that some modification of catalysts occurred during the reaction, particularly connected with the consecutive oxidation of glycerate to tartronate (glycolate selectivity remaining almost stable). In particular $1 \% \mathrm{Au} / \mathrm{TiO}_{2}$ (THPC) and $1.5 \% \mathrm{Au} / \mathrm{TiO}_{2}$ (WGC) represent the most stable catalyst showing $S_{50}$ only slightly higher than $S_{90}$. Note that $S_{50}=S_{90}$ in the case of glycolate and tartronate confirms glycolate not to be produced from tartronate. Moreover, by comparing the catalytic data from Au-PVA supported on $\mathrm{TiO}_{2}$ and activated carbon, it can be seen that the support has a strong effect on activity.

\section{Conclusions}

A number of $\mathrm{Au} / \mathrm{TiO}_{2}$ catalysts were synthesised using different preparation methods including various reduction procedures, and the catalysts characterised by HRTEM and XPS and evaluated in the liquid phase oxidation of glycerol. It has been demonstrated that the use of different reduction method (calcination versus chemical reduction) has a crucial effect on the oxidation state of $\mathrm{Au}$ and on the gold particle dimension with consequence on the catalytic behaviour in the liquid phase oxidation of glycerol. Depending on the reduction method utilised we can highlight the following points:

- Calcination sometimes resulted in the significant growth of gold particles (ranged from 5 to $25 \mathrm{~nm}$ ), while two oxidation states could be observed with metallic $\mathrm{Au}^{0}$ to be the major component, whereas $\mathrm{Au}^{\mathrm{III}}$ or $\mathrm{Au}^{\delta+}$ species the minor. The distribution or the existence of these components depends from the calcination procedure.

- Chemical reduction resulted in the formation of gold particles in the range of $2-5 \mathrm{~nm}$ and in a narrower particle size distribution. In addition XPS analysis confirmed only the presence of gold in the metallic state.

- The evaluation of the catalytic data in addition with the XPS and TEM data indicate that metallic gold was the active phase during glycerol oxidation over these catalysts.

- An increase of Au particle size will lead to a suppression of the over-oxidation and could be used as a handle to steer selectivity's in oxidation reaction.

- Investigating different preparation methods it was found that deposition-precipitation method followed by chemical reduction (e.g. $\mathrm{NaBH}_{4}$ as the reducing agent) resulted in the most active catalyst.

- Protective agents (PVA or THPC) when preformed sols are used as catalyst precursors play a role in determining the activity.

\section{Acknowledgements}

The authors are grateful for financial support from the Auricat EU network (HPRN-CT-2002-00174) and Dr. Benedicte Thiebaut from Johnson Matthey for the HRTEM analysis.

\section{References}

[1] M. Haruta, S. Tsubota, T. Kobayashi, H. Kageyama, M.J. Genet, B. Delmon, J. Catal. 144 (1993) 175.

[2] M. Haruta, T. Kobayashi, S. Tsubota, Y. Nakahara, Chem. Express 3 (1988) 159.

[3] S. Tsubota, N. Yamada, M. Haruta, T. Kobayashi, Y. Nakahara, Chem. Express 5 (1991) 349. 
[4] F. Moreau, G.C. Bond, A.O. Taylor, J. Catal. 231 (2005) 105.

[5] M. Haruta, A. Ueda, A. Tsubota, R.M. Torres Sanchez, Catal. Today 29 (1996) 443.

[6] M. Haruta, A. Ueda, G.R. Bamwenda, R. Taniguchi, M. Azuma, Proc. Int. Workshop on Catal. Combustion, Tokyo, April, 1994, pp. 2-9.

[7] A. Ueda, M. Haruta, Shigen Kankyo Taisaku (Resources and Environment) 28 (1992) 1035.

[8] M. Haruta, N. Yamada, T. Kobayahsi, S. Iijima, J. Catal. 115 (1989) 301.

[9] R.M. Torres Sanchez, A. Ueda, K. Tanaka, M. Haruta, J. Catal. 168 (1997) 125.

[10] M.J. Kahlich, H.A. Gasteiger, R.J. Behm, J. Catal. 182 (1999) 430.

[11] R.D. Walters, J.J. Weimer, J.E. Smith, Catal. Lett. 30 (1995) 181

[12] T. Hayashi, M. Haruta, Shokubai, Catal. Catal. 37 (1995) 72.

[13] T. Hayashi, K. Tanaka, M. Haruta, Preprints for Symposia on Heterogeneous Hydrocarbon Oxidation, New Orleans, 1996, Am. Chem. Soc. Vol. 41, 1996, pp. 71-74.

[14] B.S. Uphade, Y. Yamada, T. Nakamura, M. Haruta, Appl. Catal. A 215 (2000) 137.

[15] T. Hayashi, K. Tanaka, M. Haruta, J. Catal. 178 (1998) 566.

[16] Y.A. Kalvachev, T. Hayashi, S. Tsubota, M. Haruta, J. Catal. 186 (1999) 228.

[17] B.S. Uphade, T. Akita, T. Nakamura, M. Haruta, J. Catal. 209 (2002) 331.

[18] E.E. Stangland, K.B. Stavens, R.P. Andres, W.N. Delgass, J. Catal. 191 (2000) 332.

[19] G. Mul, A. Zwijnenburg, B. Linden, M. Makkee, J.A. Moulijn, J. Catal. 201 (2001) 128.

[20] C. Qi, T. Akita, M. Okumura, M. Haruta, Appl. Catal. A 218 (2001) 81.

[21] H. Sakurai, A. Ueda, T. Kobayashi, M. Haruta, J. Chem. Soc. Chem. Commun. (1997) 271.

[22] D. Andreeva, V. Idakiev, T. Tabakov, A. Andreev, J. Catal. 158 (1996) 354.

[23] T. Tabakova, V. Idakiev, D. Andreeva, I. Mitov, Appl. Catal. A 202 (2000) 336.

[24] M. Mokhtar, T.M. Salama, M. Ichikawa, J. Colloid Interf. Sci. 224 (2000) 336.

[25] L. Prati, M. Rossi, J. Catal. 176 (1998) 552.

[26] C. Bianchi, F. Porta, L. Prati, M. Rossi, Topics Catal. 13 (2000) 231.
[27] C. Milone, R. Ingoglia, A. Pistone, G. Neri, S. Galvagno, Catal. Lett. 87 (2003) 201.

[28] C.L. Bianchi, P. Canton, N. Dimitratos, F. Porta, L. Prati, Catal. Today 102 (2005) 203

[29] N. Dimitratos, F. Porta, L. Prati, Appl. Catal. A 291 (2005) 210.

[30] Ullmann's Encyclopedia of Industrial Chemistry, electronic release, Wiley-VCH, 2002.

[31] H. Kimura, K. Tsuto, T. Wakisaka, Y. Kazumi, Y. Inaya, Appl. Catal. A 96 (1993) 217.

[32] A. Abbadi, H.V. Bekkum, Appl. Catal. A 148 (1996) 113.

[33] R. Garcia, M. Besson, P. Gallezot, Appl. Catal. A 127 (1995) 165.

[34] S. Carrettin, P. McMorn, P. Johnston, K. Griffin, G.J. Hutchings, Chem. Commun. (2002) 696.

[35] S. Carrettin, P. McMorn, P. Johnston, K. Griffin, C.J. Kiely, G.J. Hutchings, Phys. Chem. Chem. Phys. 5 (2003) 1329.

[36] P. Fordham, R. Garcia, M. Besson, P. Gallezot, Stud. Surf. Sci. Catal. 101 (1996) 161

[37] P. Fordham, R. Garcia, M. Besson, P. Gallezot, Appl. Catal. A 133 (1995) L179.

[38] D.I. Enache, J.K. Edwards, P. Landon, B. Solsona-Espriu, A.F. Carley, A.A. Herzing, M. Watanabe, C.J. Kiely, D.W. Knight, G.J. Hutchings, Science 311 (2006) 362.

[39] J.-D. Grunwaldt, C. Kiener, C. Woegerbauer, A. Baiker, J. Catal. 181 (1999) 223.

[40] J.M. Fisher, Gold Bull. 36 (2005) 155, and reference cited therein.

[41] A.M. Visco, F. Neri, G. Neri, A. Donato, C. Milone, S. Galvagno, Phys. Chem. Chem. Phys. 1 (1999) 2869.

[42] A. Zwijnenburg, A. Goossens, W.G. Sloof, M.W.J. Craje, A.M. Kraan, L.J. Jongh, M. Makkee, J.A. Moulijn, J. Phys. Chem. B 106 (2002) 9853.

[43] R. Zanella, C. Louis, Catal. Today 107-108 (2005) 768.

[44] P. Konova, A. Naydenov, C.V. Venkov, D. Mehandjiev, D. Andreeva, T. Tabakova, J. Mol. Catal. A 213 (2004) 235.

[45] F. Porta, L. Prati, M. Rossi, S. Coluccia, G. Martra, Catal. Today 61 (2000) 165.

[46] N. Dimitratos, J.A. Lopez-Sanchez, D. Lennon, F. Porta, L. Prati, A. Villa, Catalysis Lett. 108 (2006) 147. 